\section{SOI: 1.1/TAS DOI: 10.15863/TAS International Scientific Journal Theoretical \& Applied Science}

p-ISSN: 2308-4944 (print)

e-ISSN: 2409-0085 (online)

Year: 2017

Issue: 12

Volume: 56

Published: 20.12.2017
Avaz Jamolovich Kakhkharov

PhD student of marketing department, Tashkent State University of economics, Tashkent, Uzbekistan. avaz_qaxxorov@mail.ru +99890-966-50-31

SECTION 31. Economic research, finance, innovation, risk management.

\title{
"UZBEK MODEL" OF DEVELOPMENT FAMOUS FOR THE NAME OF ISLAM ABDUGANIYEVICH KARIMOV CURRENTLY APPRECIATED BY THE WORLD COMMUNITY
}

Abstract: This article is devoted to the research of the famous "Uzbek model" of the development which widely recognized and appreciated throughout the world associated with the name of Islam Abduganiyevich Karimov. The main aim of researching recognition and appreciation of the "Uzbek model" by the world community is, first of all, a comprehensive study of the activity of Islam Karimov as a founder of the democratic state and civil society which he could achieve after gaining the independence by a hard work. Moreover, the article pursues the aim to publicize the contribution of Islam Karimov as the creator of "Uzbek model" to the development of the world relations. The results of the research can facilitate perpetuation of the outstanding performance and valuable inheritance of our First President, Islam Karimov. In addition, achievements gained by Uzbekistan during such a short period of time can serve as an appropriate experience for the developing countries of the world.

Key words: Islam Karimov as a founder of the independent uzbek state, "Uzbek model", world development, recognition of the international community, economic independence, "shock therapy", "Made in Uzbekistan" label, peace and cooperation, religious tolerance, professional diplomacy, single transport data sett system.

Language: English

Citation: Kakhkharov AJ (2017) "UZBEK MODEL" OF DEVELOPMENT FAMOUS FOR THE NAME OF ISLAM ABDUGANIYEVICH KARIMOV CURRENTLY APPRECIATED BY THE WORLD COMMUNITY. ISJ Theoretical \& Applied Science, 12 (56): 28-39.

Soi: http://s-o-i.org/1.1/TAS-12-56-7 Doi: crossef https://dx.doi.org/10.15863/TAS.2017.12.56.7

\section{INTRODUCTION}

Currently it is impossible to imagine that Uzbekistan, which is actively integrating into the international community, 27 years ago used to be under the influence of a former totalitarian dictatorial regime, but at present time is one of the leaders among the countries of Central Asia. The ideas and programs that Islam Karimov put forward with a clear vision of the future of Uzbekistan during that difficult period of time, clearly demonstrate the great confidence that he had expressed to our country's bright future. Therefore, the questions "why" and "how was it possible" referred to the achievements of Uzbekistan made within 25 years, are recognized and highly appreciated by the world community.

\section{UREGENCY OF THE RESEARCH}

All the great achievements and outcomes of the people of Uzbekistan during the years of independence are associated with the name and performance of the first President of Uzbekistan. The founder of the independent Republic of Uzbekistan
Islam Abduganiyevich Karimov gained a high reputation in the country and the international cooperation as a great statesman who had developed and implemented a comprehensive strategy of constructing a legal democratic state based on the civil society and market economy. It should be noted that international experts have thoroughly studied and highly appreciated so-called "Uzbek model" of the development that could withstand any crises or obstacles and currently this model is associated with the name of Islam Karimov.

Islam Abduganiyevich Karimov supported the idea that political independence can not be achieved without the achievement of economic independence and with the account of this concept he worked out the "Uzbek model" of the development based on five principles which later became wide-known and highly appreciated throughout the world leaders. This model represents the program for implementing reforms in the economy and structural changes in Uzbekistan. Therefore, in our opinion, it is necessary to conduct a comprehensive study of the activity of

ISPC Generalization of scientific results, 
Islam Karimov as a founder of the democratic liberal state and civil societies as well as his contribution as the creator of "Uzbek model" to the development of the world economy and these facts prove topicality of our research.

\section{STEPS TO ACHIEVE INDEPENDENCE OF UZBEKISTAN}

By the 90s of the 20th century, the political influence of the leading countries in the world resulted in the collapse of the former Soviet Union. This led to the formation and occurrence of new independent states in the world map. In Uzbekistan the founder of independence I.A. Karimov carefully prepared those processes in advance and developed a set of measures to overcome possible problems. I. A. Karimov was the first among leaders of the CIS countries to set up the presidency and on August 31, 1991, Uzbekistan proudly proclaimed its independence. Since the first days of the independence, under heavy and complicated issues, our First President devoted all his life to ensure peace, happiness and prosperous future not only for Uzbekistan but also in the whole Central Asia region.

\section{NECESSITY FOR THE NEW DEVELOPMENT MODEL TO SOLVE SOCIO- ECONOMIC PROBLEMS}

By the end of the 80 s of the 20th century, the economic constraint became extremely sharp and risky. This was primarily due to the complete decline in manufacturing, non-provision of the production capacity with work, the growth of the unemployment rate, non-compliance of the monetary and fiscal political systems. The main economic indicators such as GDP, national income, and labor productivity had been steadily declined. Foreign trade turnover declined, negative balance of foreign trade and public debt increased and continuous inflation was irritating everybody. As a result, incomes and living standards of the people in such poor conditions had been steadily declined. A constant reduction in the scale and volume of production made a more several impact on the living standards of the population, particularly in terms of Uzbekistan with a sharp demographic environment. Uzbekistan turned to be one of the last among the former Soviet republics with its national income per capita, real income, salary, and labor productivity.

Uzbekistan used to be ranked the 12 th by GDP per capita, while national income per capita was twice lower than the average national income in the territory of the former Soviet Union. In terms of industrial labor productivity during this period, Uzbekistan was 40 per cent below the average ratio and labor productivity in the agricultural sector was almost twice lower. The share of the production of consumer goods per capita in the Republic of
Uzbekistan accounted for 40 per cent of the exSoviet Union level [2].

Due to the cotton exported from Uzbekistan, other raw materials were imported in our country and the difference between the products exported and the products imported accounted for 898 million rubles lower. Meat, dairy products and eggs consumed by the population of the Republic amounted to 50 per cent in relation to the average population. The majority of the population earned only about 70 rubles a month. Ultimately, the infant mortality rate was one of the highest in the world, and the worst thing was that in the early 1990s, the country approached the state of famine and the reserves of the grain were enough only for 12-15 days.

As a result, there was an imbalance in the economy of Uzbekistan and social sphere. In particular, the problem of unemployment increased and reached its peak in 90-years period of time. There were 9 million unemployed in the former Soviet Union and one million of them lived in Uzbekistan.

At that time reputable organizations and experts in foreign countries were aware of this complicated situation in Uzbekistan. Therefore, at the beginning of the 90 s of the 20th century, the most influential newspapers of the nearest foreign countries published articles about our country on such topics as "Uzbekistan is a boiling samovar", "Uzbekistan is the country of starving", and "Before sunset". Many observers predicted that the country was about to experience a terrible crisis and it was impossible even to imagine its consequences.

In the book entitled "Islam Karimov-the New President of Uzbekistan" written by the great lawyer Leonid Levitin and Donald S. Carlyle from the USA on political issues in Central Asia the authors wrote that "in the early 1990s none of the Soviet Union republics experienced such difficult and terrible conditions as Uzbekistan did. The people of the republic were forced to work hard under conditions of cotton monopoly, lack of resources needed for living and generally suffering from unfair social order".

Islam Abduganiyevich Karimov at that time was the only government leader who was thinking about the people and how to deal with those difficult socio-economic issues and overcome obstacles. However, all of these unresolved issues were a political game coordinated by the central government of the former Soviet Union and Karimov on his own initiative put an end to that political game. Thus it became possible to overcome the issues of administration and commanding over the economy of our country.

\section{HISTORY OF DEVELOPING "UZBEK MODEL"}


Whenever a society turns from one regime to another, it undoubtedly tries to choose a specific and appropriate way of the development process to study errors and accomplishments of developed nations. After achieved the independence, our young country faced a very interesting issues on national state building. Even at that time, some media resources spread information about relevancy and favour of Turkish, Chinese or Korean models as a development way for our country.

Undoubtedly, during the first years of the independence our so-called "big brothers" tried to give their own proposals from outside. Some proposed the way of "Curing by paralyzing", the others proposed the "Turkish model" of the development, the thirds, relying on our cooperation with South Korea, promoted the Korean model for the development of Uzbekistan. They made conclusions based on their upbringing knowledge and didn't consider the necessity to create economic, legal and political base without taking into account customs, traditions and mentality of the people after gaining the independence [3].

Then it was suggested that other models from Malaysian, American, and Southeast Asian countries should be copied and although they were applied in other industrialized countries. They did not match the values and mentality of our nation. In some cases several "ready" recipes were steadily repeated. One of them was so-called "shock therapy". However, this model could boost the economy of the country and overcome crisis but at the expense of making 40 per cent of the working population unemployed, worsening living standards and strengthening the social constraint.

President Islam Karimov strongly believed that such kinds of approachs for market relations were inaccurate and unacceptable and our main task was move to a new stage of socio-economic development without any losses.

Under difficult conditions the idea of choosing our own way and standards of the socio-economic development were very important so it was natural to put the question on which global or regional model could Uzbek model easily and rapidly comply with. Islam Karimov strongly insisted on the point that Uzbekistan had to follow its own way of development and possess its own development model with the account of country's unique conditions and opportunities, economic and cultural tiers arisen as a result of short period and long-term cooperation.

The model for the economic development of Uzbekistan is based on the historical background, experience of our people, national customs and traditions [10]. This idea was developed and promoted by the President of Uzbekistan and later on it became famous almost all over the world with its principle "Don't destroy the old house without building a new one".
The complete breakdown of the previous system, existing economic relations and old economic relations were gradually transformed into new market and it became possible to transit to the efficient market economy system. Taking into account the structure of the economy and population of our country, the level of development of the country at the time and the way of gradual transition to the market economy were more acceptable as it could avoid political shocks.

The liberalization of foreign economic activity and the integration into the world economy also represented a complicated and difficult process for a country that had gained independence. The head of our country clearly identified the most important directions and destinations regarding valuable "Uzbek Model". As an equal member of the world community, Uzbekistan intensified opportunities for bilateral and multilateral trade and expanded economic relations with all the countries of the world.

One of the main priority of the renewal was a particular attention to the changes in the agrarian sector. The solution of the problem of land ownership, the elimination of state-owned enterprises, especially low-efficient and loss-causing collective and cooperative farming, the transfer of their land to farms or dehkan household on the longterm basis and the involvement of unskilled labor in industrial enterprises constituted the main issues in the agrarian policy of Uzbekistan as well as the priority of the strategy of transition to the market economy. Ensuring macroeconomic stability, implementing a thoroughly elaborated financial policy, achieving radical changes and transformations in the economy were also considered to be the most important advantages for the elimination of the image of our republic as a raw material base.

In general, Islam Karimov determined the essence and peculiarities of the model for the national development which has been widely recognized as the "Uzbek model of the development" in the world at present times since the early years of independence.

In the aftermath our own way of the development gained a worthy place among German, Swedish, Chinese and Japanese models. Uzbekistan efficiently applied all the advantages and positive experience accumulated by the countries in the process of their development. The point was not to simply copy any model even though it could provide positive results. Certain technique and methods designed for a particular country can bring a positive effect only in the specific conditions of that country [4].

The five main principles of the transition to the market relations in Uzbekistan which were determined by the head of our state justified results 
of consistent, sound and long-term pursuit of efficient and wise policy. In this regard, Uzbekistan selected its own way of the development. This approach was developed with the account of the experience of advanced countries and aimed at the creation of the national model of economic reforms. So far, as results of the comprehensive analysis of the existing situation created Uzbek model" by the First President were widely recognized and appreciated.

\section{BRIGHT FUTURE OF UZBEKISTAN}

Evidence-based response worked out by us 26 years ago to the questions "What should be done? How should we start? How can we achieve these accomplishments?" is recognized throughout the world and its efficiency is being studied. However, at that time, the situation was more complicated and uncertain, the first stage of privatization in the republic was not over yet, independence of fuel and energy resources and grain hadn't been achieved yet, industry as well as the whole economy hadn't gained macroeconomic stability, and the country couldn't leave a ruble zone yet. The national currency hadn't been introduced, there were scarcity and inflation, the chaotic, uncontrolled system of prices and taxes, the unbalanced exchange rate, and the bank interest rates became really unbearable.

At that time the President Islam Karimov fearlessly began to gradually implement newly created Uzbek model. It should be noted that the President of Uzbekistan created the model which wasn't expected by world famous policy-makers and economists. Moreover, he promoted the following idea: "Speaking about economic freedom and economic independence we should never forget about one important point: economic independence is the main independence, and it is impossible to achieve political independence without economic independence". And that economic independence will never be political independence unless it is a fundamental independence, economic independence",

From the first day when Karimov was elected as a president, he started working to ensure the peace and tranquility of his population. Moreover, maintaining of peace and stable safety as the glorious treasure of the world were one of the most important and priority ideology of Islam Karimov's leadership.

He could realize great accomplishments which were not implemented by any state leader or commanders before. That is, Islam Karimov curbed the interethnic constraint, extinguished the civil war, saved lives of hundreds of thousands or millions of people, and provided peace and tranquility in our republic and in the multinational region of Central Asia region.

On December 8, 1992 the Constitution of the Republic of Uzbekistan was adopted on the initiative of Islam Karimov and it constituted the legal basis of the independent state building.

The First President paid a particular attention to social issues, primarily to the development of healthcare system to ensure the health of our people, and the government programs aimed at improving the welfare of the population and their future. In particular, he was the creator of the program for further deepening of economic reforms and developing of a civil society, the National Program on Personnel Training, the qualitative changes in the field of education and healthcare, the gradual development of children's sports, the construction of housing and infrastructure based on model projects in rural areas.

Rich customs and traditions of the Uzbek people have been restored. The names of famous scholars and poets, great statesmen, and the generals who sacrificed their lives for the country were honored. The national and spiritual heritage of Imam al-Bukhari, Imam at-Termizi, Bahouddin Nakshband, Khoja Ahmad Yassaviy, Al-Khorezmiy, AlFerghani, Ibn Sino, Mirzo Ulughbek, Alisher Navoi, Zahiriddin Bobur and many other great ancestors who had contributed greatly to the development of our national culture and world civilization were returned to our people, their birthdays were celebrated throughout the country, their souls were remembered, their works were published and historical monuments, mosques, museums registered under UNESCO heritage. Their cultural inheritance contributes to the efforts of our people in building a new society and facilitates the spiritual renewal of our community.

Since early days of independence Karimov established diplomatic relations and cooperation with many foreign countries. Total world saw the Uzbek people as the reflection of Islam Karimov.

While Uzbekistan was following the choosen way of development, Islam Karimov was the first among the CIS countries to promote the idea of setting up modern farms, supporting small business and private entrepreneurship, developing privatization and competition, and modernizing the manufacturing and service sectors, industries through the national entrepreneurship. Thanks to the wise policy of Islam Karimov during the years of independency our economy has grown almost six times, the real income per capita has risen by more than twelve times, and our gold and foreign exchange reserves have grown steadily. The share of industry increased from 14 per cent to 34 per cent. Growth rates of gross domestic product for the last decade have been keeping stable. Gratifyingly, the economy of Uzbekistan has become among the five fastest growing countries of the world.

Islam Abduganiyevich Karimov was an unique world-class leader which built world standard state building policy like Ustyurt and Shurtan gas- 
chemical complexes, Bukhara oil refinery, Kungrad soda plant, Dehkanabad potash fertilizer plant could be mentioned. The construction of large automobile plants such as GM Uzbekistan, SamAuto and MAN Auto-Uzbekistan has enabled to produce vehicles which can comply with new international standards.

Under the leadership of the First President Islam Karimov, modern roads and transport logistics infrastructure were built in Uzbekistan. In particular, the Angren-Pop railway system with a unique tunnel through the Kamchik pass was built. High-speed railway train launched, international airports were modernized. At the same time, Uzbekistan created comprehensive opportunities for the development of private property, entrepreneurship and small business. A new social layer - entrepreneurial class appeared in Uzbekistan. The consistent growth of the number of joint ventures established entirely at the expense of foreign capital is connected with the creation of a favorable investment climate for investors. This was evidenced by the fact that during the years of independence the investments in the amount of 190 billion USD, including foreign investments in the amount of 65 billion USD were attracted in the economy of Uzbekistan.

Uzbekistan is an attractive country for investments. This can be justified by the fact that famous joint-ventures - "General Motors", "MAN", "Klaas", "Isuzu", "Lotte chemical", "Kogas", "Daewoo Textile", "Yang Von", "Huawei", "Peng Sheng", "Maxam", "Indorama", "Nestle", "Nobel", "Rither" were established with the participation of foreign investors from over 90 countries such as the United States, Germany, Japan, South Korea, China, Spain, Switzerland, Singapore. Currently more than 4,000 joint ventures are successfully operating in our country. Cooperation with them enables to implement radical modernization of the national economy, introduction of modern technologies, improvement of production management, active access into the world markets with new products.

The creation of Navoi Free Industrial Economic Zone, Angren and Jizzakh Special Industrial Zones which provided investors wide tax concessions and preferences contributed to the development of hightech enterprises. In addition, Gijduvan, Urgut and Khazarasp free economic zones and small industrial zones were established in 2017.

Nowadays cars and telecommunication equipment, computers and mobile phones, a wide range of consumer electronics, and many other products with the label of "Made in Uzbekistan" can be found not only in local but also in many foreign trade malls. Due to the ongoing global crisis when in many countries the demand for consumer goods is decreasing, in the middle of the current year 493 new enterprises were involved in export activities with resulted in production of 168 types of products and total sales in the world markets is over 64 million USD.

\section{CHALLENGES OF UZBEK MODEL OF DEVELOPMENT TO THE WORLD COMMUNITY}

Over the past 26 years, the concept of "Uzbek model" has come into our reality. Though it is not a long term for the history within a short period of time, the Uzbek model has successfully passed through three major challenges as a protection pillar of the economy.

1. First challenge. It was a transitional period of the young independent country covering the 90 s of the last century. At the same time Uzbekistan was the first among the countries of the former Soviet Union to achieve macroeconomic stability and growth in the production of industry and Gross Domestic Product (GDP). In other words, the development turned out to be the only acceptable way to overcome negative consequences of the crisis.

2. Second challenge. Global financial crisis 2008. The development model has not only contributed to mitigation of the global financial and economic crisis, but also enabled to maintain the highest rate of economic growth (up to 8 percent per year) among 10 countries of the world.

In this regard Islam Karimov also published the book by name of "The global financial and economic crisis, ways and measures to overcome it in conditions of Uzbekistan". This book represented anti-crisis measures for 2009-2012 aimed at eliminating the negative effects of the global economic crisis and contains the program proposing the concept of a stronger, more stable and balanced development of the Uzbek economy after the crisis. Thus it's not an exaggeration to say that the concepts developed by the First President in this book, made a valuable contribution to the economic theory.

3. Third challenge. Current changes occurring in the international markets and the unreserved disagreements for fuel and energy resources, as well as the political and economic scandals in Arab countries are the major factor for the instability of many leading and emerging economies in the world accompanied with a sharp decline in their exports. On the contrary, the stability of Uzbek economy and enhancing the volume of exports once again justify the fact that Uzbek model of the development successfully passed the test and responded to the challenge of the world community.

\section{MAIN RESULTS OF UZBEK MODEL AND ITS PROSPECTS}

Consequently, the main results of the "Uzbek model" of our republic are the fact that even though Uzbekistan hasn't achieved the accomplishments of the leading countries of the world, it could achieve 
significant results in the social sphere. All All the programs of the "human factor" developed by the UN have been proven in Uzbekistan during the years of independence. In particular, appropriate activities aimed at the development of healthcare, science, culture and arts, sports - the spheres which are of vital importance to our society, the attention and care to older generation, women and youth, ensuring their rights and interests, protection of family, motherhood and childhood have been undertaken. At the same time, annual expenditures of the state budget on social spheres have gradually increased and over the past 10 years this indicator has exceeded 60 per cent.

The issue of upbringing the young generation as healthy and harmoniously developed people has become the most important aspect of the government policy. For this purpose, the Fund for the Development of Children's Sports as well as a threetier sports competitions system have been established. At the expense of the Fund, about 300 music and art schools and over 1900 sport facilities have been built in all provinces, cities and districts. During the last decade, regular sports involvement among children and teenagers has risen from 30 to 57 per cent, and among girls - from 24 per cent to 47 per cent. In this regard, the reputation of our country in the world ratings is increasing year by year.

On the initiative of the United Nations, scholars from the Columbia University in the United States have traveled to 158 countries to conduct social studies. According to the indicator "Worldwide Happiness Index" announced on the basis of the results of this survey, Uzbekistan was ranked 44th out of 158 countries involved in that study and recognized first among the Commonwealth of Independent States. It should be noted that as a result of significant improvement of the living standards of the population the maternal mortality rate has decreased by more than 2 times, infant mortality - by 3 times. Moreover, average life expectancy has prolonged from 67 to 73 years, and an average life expectancy of women has reached 75 years.

Winning 4 gold, 2 silver and 7 bronze medals at the XXI Summer Olympics in Rio de Janeiro, Brazil on 5-21 August, 2016 became a great victory for our policy aimed at developing the youth sports.

Our national economy has rapidly changed not only in terms of the size but also in terms of the quality. The share of industrial and service sectors have been steadily rising in the Gross Domestic Product.

Since the first years of independence, Islam Karimov set up a crucial task to solve food problems due to our own reserves, in particular, grain independence. Structure of cultivated lands, placement of agricultural crops was reconsidered and redistributed with the account of internal demand and conditions. Cotton didn't remain as the only agriculture. As a result, food security and grain independence have been ensured in our country. Over the past years grain production has grown by 7 times, while grain yields have increased by more than 3 times.

A particular attention is being paid to the development of small businesses and private entrepreneurship with the account of the experience of the developed countries and the entrepreneurial skills and craftsmanship of our people.

Currently the share of non-government sector in the economy has exceeded 83 per cent. The share of small business and private entrepreneurship in the Gross Domestic Product increased by 54 per cent. Almost 98 per cent of agricultural products belong to the production of farmers and private entrepreneurs.

The most notable point is that small businesses and private entrepreneurship have become the most important factor which has enabled people to work freely basing on their own knowledge and skills, entrepreneurial abilities, to use the products manufactured, to own property, and to create sustainable income sources. At present, the share of income from entrepreneurial activity in the structure of the total population income accounts for over 50 per cent.

During the first years of independence, the share of food products in the total amount of imported products accounted for 73 per cent. Now this share does not exceed 10 per cent. On the contrary, from year to year the share of foodstuffs in exports is growing. At the same time, fundamental reforms in the agriculture have become the basis for changing the labor relations and the farmer became a true owner of the land. So farmers turned to be a decisive force of our society.

One of the most important and top priorities of the "Uzbek model" is a strong social policy. Market reforms have been based on this principle and it should be noted that they facilitated maintenance of social justice and stability in our society during the most difficult transition period.

Demographic situation was very complicated when our country gained its independence. There were no new work places created at all [12].

One of the most important factors of the development is undoubtedly peace and tranquility. The business community of the world also cooperates with stable, peace-loving countries where security is guaranteed.

Peace and religious tolerance in our country, atmosphere of love and interethnic harmony play an important role in the successful implementation of reforms in all spheres. That's why "The foundation for all great achievements and accomplishments of Uzbekistan in the way of independent development is peace and tranquility, interethnic and inter-civilian harmony, mutual respect and harmony" - said the First President of our country. 
The efficiency of the "Uzbek model" during 26 years is proven by the fact that Uzbekistan has occupied a worthy place in the world and achieved high goals. At present time the world leading organizations study the experience of Uzbekistan as a case study of the "Uzbek model" and forecast bright future of our country.

In particular, as of July 1, 2015, gross national incomes of the world countries per capita (calculated by World Bank Atlas method, in USD) are classified as follows [5].

Today, according to the World Bank, there are 31 countries with low income in the world, the number of lower middle income countries amounts to 51, high middle income - 53 and high income - 80 . According to World Bank statistics, in 2014, Uzbekistan GDP per capita accounted for \$2,090 and thus our country refers to the lower middle income countries.

Thus, with the aim of improving the situation and being among the countries with high middle income by 2030, with the account of current population it is necessary to double GDP per capita.

The average annual GDP growth per capita in Uzbekistan for $2004-2014$ is 7 per cent. If such growth rates are maintained within 10 years, GDP per capita can double by 2025 . It is well known that the high goals set by the government for the 2030 are the targets which can be accomplished in terms of our potential.

On January 4, 2011, one of the world largest financial institutions, HSBC Holdings plc, the «Eych-es-bi-si» bank (the largest bank in Europe and the second in the world according to the capitalization level by Forbes magazine's rating in
2011) has published an analytical study "The World in 2015" that includes forecasting indicators. Its forecasts are based on the level of development of the modern world economy and include opportunities and essential factors, such as current income per capita, law priority, democracy, education, and demographic changes in developing and market transition countries included.

Analysts determined 100 countries with probable achievements of the highest ratings by the economic growth according to three categories: Rapid growth (average annual growth of more than 5 per cent); Growth (average annual growth rate between 3 and 5 per cent); Countries that are expected to be stable (less than 3 per cent per year).

Thus, the current state of development used to be low, but in the shortest period of time it achieved significant renewal and modernization and in the nearest future the number of countries of the first category accounted for 26. They have the opportunity to "inherit" the world's advanced technology for many years.

HSBC bank estimates that by 2050 GDP of Uzbekistan (in USD unchanged since 2010) will reach 314 billion, GDP per capita will be $\$ 8,859$ and the economic development level will rise by 22 per cent to the 51st place in the world.

In order to achieve these results, average annual GDP growth in Uzbekistan will reach 8,2 per cent 2010-2020, 6,9 per cent 2020-2030, 6,1per cent in 2030-2040, and 5 per cent in 2040-2050. The growth of income per capita for the same period is projected to rise from 6,7 per cent in 2010-2020 to 5,1 per cent in 2040-2050 (Table 1).

Forecast indicators developed by HSBC [6]

Table 1

\begin{tabular}{|c|c|c|c|c|c|c|c|c|}
\hline & \multicolumn{4}{|c|}{ Forecast of growth of income per capita } & \multicolumn{4}{|c|}{ Forecast of GDP growth } \\
\hline & $\begin{array}{l}\text { 2010- } \\
2020\end{array}$ & $\begin{array}{l}\text { 2020- } \\
2030 \text {. }\end{array}$ & $\begin{array}{l}2030- \\
2040 \\
\end{array}$ & $\begin{array}{l}2040- \\
2050\end{array}$ & $\begin{array}{l}2010- \\
2020\end{array}$ & $\begin{array}{l}2020- \\
2030 \\
\end{array}$ & $\begin{array}{l}2030- \\
2040 \\
\end{array}$ & $\begin{array}{l}2040- \\
2050\end{array}$ \\
\hline Azerbayjan & $6.1 \%$ & $5.4 \%$ & $4.8 \%$ & $4.4 \%$ & $7.0 \%$ & $5.7 \%$ & $5.0 \%$ & $4.1 \%$ \\
\hline Bangladesh & $3.6 \%$ & $4.4 \%$ & $5.0 \%$ & $5.5 \%$ & $5.5 \%$ & $5.5 \%$ & $5.6 \%$ & $5.5 \%$ \\
\hline China & $6.5 \%$ & $5.7 \%$ & $5.1 \%$ & $4.6 \%$ & $6.7 \%$ & $5.5 \%$ & $4.4 \%$ & $4.1 \%$ \\
\hline India & $4.0 \%$ & $4.5 \%$ & $4.8 \%$ & $5.1 \%$ & $5.7 \%$ & $5.6 \%$ & $5.5 \%$ & $5.2 \%$ \\
\hline Indonesia & $3.0 \%$ & $3.7 \%$ & $4.2 \%$ & $4.7 \%$ & $4.3 \%$ & $4.3 \%$ & $4.3 \%$ & $4.5 \%$ \\
\hline Kazakhstan & $5.9 \%$ & $5.2 \%$ & $4.7 \%$ & $4.3 \%$ & $6.1 \%$ & $5.8 \%$ & $4.9 \%$ & $4.0 \%$ \\
\hline South Korea & $3.7 \%$ & $3.4 \%$ & $3.1 \%$ & $3.0 \%$ & $3.7 \%$ & $2.3 \%$ & $1.8 \%$ & $1.7 \%$ \\
\hline Malaysia & $5.4 \%$ & $4.6 \%$ & $4.1 \%$ & $3.6 \%$ & $7.1 \%$ & $5.7 \%$ & $4.7 \%$ & $3.8 \%$ \\
\hline Pakistan & $1.5 \%$ & $2.5 \%$ & $3.5 \%$ & $4.4 \%$ & $4.0 \%$ & $4.5 \%$ & $4.9 \%$ & $5.0 \%$ \\
\hline Philippines & $6.1 \%$ & $5.6 \%$ & $5.2 \%$ & $4.8 \%$ & $8.4 \%$ & $7.3 \%$ & $6.6 \%$ & $5.8 \%$ \\
\hline Singapore & $3.6 \%$ & $3.2 \%$ & $2.7 \%$ & $2.3 \%$ & $3.7 \%$ & $2.1 \%$ & $2.0 \%$ & $2.1 \%$ \\
\hline Sri Lanka & $5.2 \%$ & $5.2 \%$ & $5.0 \%$ & $4.9 \%$ & $5.4 \%$ & $5.3 \%$ & $4.9 \%$ & $4.3 \%$ \\
\hline
\end{tabular}

ISPC Generalization of scientific results, 


\begin{tabular}{|c|c|c|c|c|c|c|}
\hline Impact Factor: & $\begin{array}{l}\text { ISRA (India) } \\
\text { ISI (Dubai, UAE } \\
\text { GIF (Australia) } \\
\text { JIF }\end{array}$ & $\begin{array}{l}=1.344 \\
=0.829 \\
=0.564 \\
=1.500\end{array}$ & $\begin{array}{l}\text { SIS (USA) } \\
\text { PИНЦ (Russia) } \\
\text { ESJI (KZ) } \\
\text { SJIF (Morocco) }\end{array}$ & $\begin{array}{l}=0.912 \\
=0.207 \\
=4.102 \\
=\mathbf{2 . 0 3 1}\end{array}$ & $\begin{array}{l}\text { ICV (Poland) } \\
\text { PIF (India) } \\
\text { IBI (India) }\end{array}$ & $\begin{array}{l}=6.630 \\
=1.940 \\
=4.260\end{array}$ \\
\hline
\end{tabular}

\begin{tabular}{|l|l|l|l|l|l|l|l|l|}
\hline Thailand & $3.7 \%$ & $4.0 \%$ & $4.1 \%$ & $4.2 \%$ & $4.0 \%$ & $3.8 \%$ & $3.8 \%$ & $4.0 \%$ \\
\hline Turkmenistan & $\mathbf{6 . 1 \%}$ & $\mathbf{5 . 5 \%}$ & $\mathbf{4 . 9 \%}$ & $\mathbf{4 . 5 \%}$ & $\mathbf{7 . 7 \%}$ & $\mathbf{6 . 4 \%}$ & $\mathbf{5 . 6 \%}$ & $\mathbf{4 . 5 \%}$ \\
\hline Uzbekistan & $\mathbf{6 . 7 \%}$ & $\mathbf{6 . 0 \%}$ & $\mathbf{5 . 5 \%}$ & $\mathbf{5 . 1 \%}$ & $\mathbf{8 . 2 \%}$ & $\mathbf{6 . 9 \%}$ & $\mathbf{6 . 1 \%}$ & $\mathbf{5 . 0 \%}$ \\
\hline Vietnam & $4.7 \%$ & $4.9 \%$ & $5.2 \%$ & $5.5 \%$ & $5.7 \%$ & $5.3 \%$ & $5.1 \%$ & $4.8 \%$ \\
\hline Average in Asia & $4.8 \%$ & $4.6 \%$ & $4.5 \%$ & $4.4 \%$ & $5.8 \%$ & $5.1 \%$ & $4.7 \%$ & $4.3 \%$ \\
\hline
\end{tabular}

From the data stated in Table 1 it is obvious that by 2015 the highest and the most reliable indicator of average annual growth of the GDP belong to Philippines and Uzbekistan among Asian countries.

\section{RECOGNITION OF THE "UZBEK MODEL" OF DEVELOPMENT BY THE WORLD COMMUNITY AT PRESENT TIMES}

The ideas, concepts and proposals developed by the First President Islam Karimov in his book "The world financial and economic crisis, ways and measures to overcome it in conditions of Uzbekistan" were appreciated by Lee Fenlin, the member of State Council of China at the International scientificpractical conference held in Tashkent on May 22, 2009. He mentioned that "It is important to study the experience of Uzbekistan and to take an example from it. It should be noted that Uzbekistan is occupying a leading position in its region". The consistent implementation of the Uzbek model radically changed the economic and social image of our country. Currently Uzbekistan has obtained a position among the few countries in the world which are developing steadily, actively and dynamically. Great achievements in social and cultural spheres are widely recognized and appreciated by prominent international organizations and experts.

Hans Joachim KNAUPE, CEO of the International Academy of Economics in Berlin, commented on this point: "The most perfect, accurate and well-developed Anti-Crisis Program of Uzbekistan, as well as the economic reforms under complicated conditions of the crisis, reflects the important priorities and measures leading to progress in the post-crisis period. It will undoubtedly serve as a promising program for many countries".

Indeed, the growth rate of GDP in the country remained stable at the point of over 8 per cent even during the world financial-economic crisis and this fact was very surprising for the world community, including international experts and famous economists.

In particular, the Mission of the International Monetary Fund (IMF) noted Uzbekistan had consistently progressed and was successfully undertaking steps to overcome consequences of the global financial crisis, and thus it became possible to give a positive forecast about maintaining high growth rates in the middle-run perspective. In this regard, the world-wide recognized "Uzbek model" of the development maintained stable high rates of economic growth and macroeconomic balance in 2012 despite the global financial crisis. In particular, last year the country's GDP grew by 8,2 per cent, industrial production - by 7,7 per cent, agricultural production - by 7,0 per cent. The state budget was executed with a surplus of 0,4 per cent in relation to the GDP. The inflation rate did not exceed the determined forecast.

According to the World Bank Group, if 10 years ago an entrepreneur needed 276 days to launch its business, currently this process requires less than a week in Uzbekistan and complies with the indicators of high income countries. Such measures aimed at improving the business environment are reflected in the rating of international economic organizations. For example, in the short run, our country improved its indicators for almost 70 points.

At present, more than three-quarters of all employed people in Uzbekistan are engaged in the private sector. They also were set up an objective to increase the volume of processing raw materials on the basis of modern technologies application, to enhance the export of ready-made goods and to develop the service sector. The proprietors and entrepreneurs, who even didn't exist 25 years ago, currently have become the dominant power of the economy.

"The Uzbek government does not make highprofile political statements and is not engaged in political aggression", - says Viktor Matyashov, the editor-in-chief of the "The World says" newspaper. It is undertaking concrete practical steps to regulate the economy and construct the state. Since the earliest days of independence, every effort made by Uzbekistan has been closely monitored by far and near neighbors. The enthusiasm for establishing contacts with the younger countries with favorable geographical conditions, natural resources and human resources has been intensifying year by year.

Implementing a reasonable and comprehensive policy on raising the living standards of low and middle income population based on the "Uzbek model" relevant measures to prevent the sharp decline in society have been taken. In 2015, the gap so called "decel factor" - between 10 per cent of wealthy population and 10 per cent of insufficiently socially-secured population accounted for 7,7 per cent. The internationally recognized Jini Index, i.e. 
the polarization indicator of the population, was 0,280, which was much lower than in many developed and developing countries.

In this regard, the following figures are noticeable: real incomes of the population increased by 11 per cent in 2016, salaries of budget organizations increased by 15 per cent, pensions and social benefits grew by 12,1 per cent. These figures indicate that our government cares about its citizens in conditions of declining social payments due to the ongoing global financial crisis.

Sustainability, the aforementioned factors, as well as the ever-improving transport industry, attractive investment climate, and high position in the international rankings - all attract new investors ready to cooperate with Uzbekistan. Investments into our economy, mainly for the implementation of projects for modernization, technical and technological renovation just in 2016 itself increased by 10 per cent and amounted to $\$ 16,6$ billion. At present time in the territory of Uzbekistan which is integrating into the world economy, over five thousand enterprises with the participation of foreign capital operate on the basis of mutually beneficial cooperation. Reforms based on the "Uzbek model" have always been highly appreciated by experts. In particular, the World Economic Forum included Uzbekistan among the five rapidly growing countries.

According to the opinion of Iveta Grigule, the chairperson of the European Parliament's delegation on cooperation with the Central Asian countries (worldnews.uz), "Uzbekistan has made unprecedented achievements during the years of independence in comparison with the situation which used to be 25 years ago. At present time Uzbekistan is demonstrating its dynamic development in all spheres. It has become the country that pays a particular attention to ensuring the safety of his citizens, improving their material welfare and social protection, and providing them with access to diverse services", - said a member of the parliament.

As a result of large-scale comprehensive reforms, the economy of Uzbekistan has grown several times, and if its population has increased by one and a half times, the income per capita has risen significantly. The look of our cities, towns and villages has radically changed, and modern production and social infrastructure has been created. All this is a practical expression of the successful implementation of the "Uzbek model" of development, the policy of reforms being pursued for the prosperity of the country and every citizen.

A major conference on the study of the rich heritage of the great scholars living in the land of Uzbekistan, in particular, the scientific heritage of Temurids, was held recently at the Leiden University in the Netherlands. There is a great deal of positive feedback not only about our ancestors, our philosophers, but also about the modern development of Uzbekistan [7].

Japanese experts also published the article on the life and activities of the First President of Uzbekistan, Islam Karimov, in "The Japan Times". The article notes that Karimov has developed a program of reforms based on five principles that are recognized as the Uzbek model of development all over the world. In addition, the article touches upon creation of completely new high-tech industries in the country, construction of world-class industrial facilities, building of modern road-transport and engineering-communication infrastructure. It should be noted, that thanks to the reforms made on the basis of the "Uzbek model" of development, Uzbekistan economy joined the list of five the most rapidly growing economies in the world.

The First President developed and implemented the Concept of foreign policy, based on Uzbekistan's commitment to peace, non-interference in the internal affairs of other states and only peaceful, political resolution of disputes. It is well-known that the head of the state made a great contribution to the maintenance of peace and stability in the region and around the world. Islam Karimov has set up the foundation for a completely new system of education and upbringing of the younger generation, who is considered to be a decisive and powerful force of today and tomorrow. In fact, the First President of Uzbekistan has dedicated his boundless love to the people and his whole life to the devotion to the motherland [8].

The world-famous "FORBES" magazine on September 14, 2017 published the article on economic reforms of Uzbekistan and on the internal and foreign policy implemented by the President Shavkat Mirziyoyev. It should be noted that the President of the Republic of Uzbekistan, Shavkat Mirziyoyev, who was elected after Islam Karimov, is being recognized as a new Uzbek leader in the world.

Shavkat Mirziyoyev has proven to the Eurasia observers and international experts that the largest military base in the region has finally been modernizing its economy and establishing friendly relations with other countries in this process.

Uzbekistan is preparing for full currency convertibility by 2019 and is developing its free trade zones through the major regions of the country. Their external debt is less than 20 per cent of GDP. When Kazakhstan started its rapid growth, Uzbekistan was still behind in GDP. However, unlike Kazakhstan, Uzbekistan has never experienced a huge debt and at the time when a sharp decline for raw materials was observed, our country has successfully overcome this difficulty. It has been recognized that in 2016, the economy of Uzbekistan, like the Chinese economy, has grown by 7 per cent.

"World Giving Index 2017" has announced a new rating paying a particular attention to the people 
of Uzbekistan. According to this rating, among other Central Asian countries, the most generous people live in Uzbekistan. According to the organizers of this rating, 40 per cent of populationin Uzbekistan deal with charity activities and in Kazakhstan this indicator accounts for 30 per cent. Uzbekistan ranks 38th in the world rankings and neighboring Tajikistan are on the 50th place and Turkmenistan is on the 69th place, Kirgizstan is on the 85 th place and Kazakhstan occupies 87th place. The rating analysis shows that in Central Asia Uzbekistan is recognized by the world community because of its way of development and a generous contribution of the population to the charity.

It is a well-known fact that the concepts and opinions expressed by Uzbekistan on the international platforms aimed at solution of urgent problems are justified. One of the most prestigious organizations in the world is the United Nations Organization in which session each speech of the President of the Republic of Uzbekistan has always been warmly welcomed by the people of the world.

Although the Republic of Uzbekistan became the UNO member on March 2, 1992, Islam Karimov made the first speech at the 48th session of the UN General Assembly in New York in 1993 on the transformation of the Central Asian region into a nuclear-weapon-free zone. As a result, the Treaty "On the establishment of a nuclear-weaponfree zone in Central Asia" came into power on March 20,2009 . This very initiative was later appreciated as a timely and reasonable initiative by Tijey Bouz, an expert at the Center for the Study of Nuclear Weapons Prevention at the Monterey Institute for International Studies.

The second participation of Islam Karimov in the UN General Assembly devoted to the UNO 50th anniversary celebration was in 1995. In his speech he promoted the idea of preventing the problem of terrorism and the conflicts in neighbore Afghanistan.

The third participation of Islam Karimov in the "Millennium Summit" of the UN General Assembly happened in 2000. In his speech he offered solutions to the challenges of international terrorism and drug trafficking; ensuring regional security, including stability and security in the Central Asian region; improving the global security system, reforming the structure and functioning of the United Nations Organization.

At his fourth participation in the plenary session of the UN General Assembly on Millennium Development Goals in 2010, Islam Karimov emphasized that security, stability and sustainable development in the region and environmental protection are among the priorities.

Proposals and recommendations aimed at solving urgent problems in the international arena have always been reflected in the international arena.
This time this tradition was followed by Shavkat Mirziyoyev at the UN summit. On September 19, 2017, at the 72nd session of the UN General Assembly the President of the Republic of Uzbekistan Shavkat Mirziyoyev has stated that it is necessary to implement the principle "human interests are superior to all". In addition, he has made proposals aimed at ensuring security of Central Asian countries and strengthening regional cooperation, solving the problems with the Aral Sea and regional water areas, peace issues in Afghanistan. Moreover, he has tackled such crucial issues as the formation of youth policy and the development of the UN Convention on the Rights of the youth, the role of mass media as well as Islam as a holy religion and tried to promote his ideas to the people all over the world.

\section{UZBEKISTAN IS A WORTHY FOLLOWER OF DEVELOPMENT}

Islam Abduganiyevich Karimov left his dear people and his beloved motherland as well as respect gained within many years to his follower who had been proven on different positions under various complicated circumstances, Shavkat Miromanovich Mirziyoyev with the words "Good luck!". On September 2, 2016 people of Uzbekistan saw off the head of the state with the greatest sorrow and grief in his last way. The whole Uzbek nation expressed the wish to continue their life and development with Shavkat Miromanovich Mirziyoyev. Wherein Shavkat Mirziyoyev started his activity on the position of the President of our country with the words: "Our dear and respected person, Islam Abduganiyevich Karimov, is not with us today. However, in our activity we will always rely on the implementation of "Uzbek model" of the development worked out by our First President as well as on strategic principles of creating a modern state".

Shavkat Miziyoyev, a devoted follower of President Karimov, began his policy with communication with the whole society. A particular attention was paid to the welfare of the people of Uzbekistan, national economy, relations of the rest countries of the world for maintenance regional peace and prosperity.

In order to achieve the goals set up by Islam Karimov it is necessary to constantly and tirelessly work on February 7, 2017 Shavkat Mirziyoyev signed the Decree No-4947 "On Action Strategy for the Further Development of the Republic of Uzbekistan".

Shavkat Mirziyoyev knew his preceptor Islam Karimov and his position to sacrifice his life to the beloved people and motherland from the first steps of independence. Therefore, President Mirziyoyev commented: "Islam Abduganiyevich Karimov was a great and wise policy-maker, long-sighted and 
strategic thinker who had the ability to perceive the complicated events and situation ongoing in the world and different regions from the all point of views of the nationhood. Moreover, he was the leader with a strong feeling of responsibility for the country and people, as well as for each citizen. Islam Abduganiyevich was elected as the leader of the country in the most complicated and difficult period of our national history with severe interethnic clashes and other contradictions, while the risk of the civil war in our country was high, our economy experienced the deepening crisis, when past days had come to the and a new prospective era started. His mercy and blessings to the beloved people of the country was invaluable. The noblest qualities of Islam Abduganiyevich, such as strong will, dedication, courage and patriotism, humanity and justice, sincerity and kindness, are a vivid example for all of us'[9].

In accordance with on January 25, 2017 the President of the Republic of Uzbekistan issued the Decree № 2744 “On perpetuation of the memory of Islam Abduganiyevich Karimov, the First President of the Republic of Uzbekistan" [13]. According to this Decree, with the aim of perpetuation of the the First President, the Hero of Uzbekistan, bright memory of Islam Abduganiyevich Karimov the following measures have been undertaken: the Republican charity fund named after Islam Karimov has been established, the mosque located in Tashkent has been given the name "Mosque of Islom ota", the scientific-cultural monumental complex named after Islam Karimov has been established in Oksaroy residence in Tashkent, museum of Islam Karimov has been founded in Samarkand, works on constructing the memorial devoted to the memory of Islam Karimov are being implemented in his motherland - Samarkand. Tashkent State Technical University, Automobile construction plant in Asaka, Museum of arts in Fergana, Tashkent International airport, avenues of cities and regions have been named after Islam Karimov. State scholarship has been introduced for the students of higher educational establishments. The 30th of January, the birthday of the First President, and the end of September, memory day are expected to be memorized.

In a short period of time, Shavkat Mirziyoyev justified the trust of the nation and his preceptor. First of all, Mirziyoyev went into the public and expressed his interest in issues of the nation and activity of entrepreneurs with sufficient government support.

In addition, he has also numerous deal and projects on innovation development of the national state building. During in this short period of time the President paid a particular attention to the foreign relations and cooperation which he could already made 25 state visits to 8 countries.
Experts in business circles and analysts say that the rational and far-sighted policy is currently being pursued by the President Shavkat Mirziyoyev, and reforms being implemented are not only effective, but also serve as a case-study for other countries on the achievements of Uzbekistan in the development of the market economy.

\section{CONCLUSION}

Grateful to the efficiency of the "Uzbek model" proven during past 26 year's period of time Uzbekistan has gained a worthy place in the international cooperation and achieved significant accomplishments. Currently reputable organizations of the world confidently believe in the great future of the Republic of Uzbekistan created based on the "Uzbek model" and highly appreciated that present time independent Uzbekistan able to cooperate and negotiate with majority countries in East and West. Islam Karimov could not had been achieved these glorious accomplishments by himself for his presidency.

The reason for this is his contribution to the prevention of the interethnic bloody conflict in the 1990s and improvement and smoothening of the situation, bringing the country in the global partnership as an independent, liberal, democratic, secular, constitutional, sovereign state, avoiding complicated circumstances and ensuring a prosperous life for the Uzbek nation. He lead the youth as his "own children" on the way of progress and stability, implementation of all reforms for the development of the country, society, mahalla and family by only continuous hard work and prospective research.

In general, the dedication of Islam Karimov to the Uzbek nation and the Motherland was reflected in his great deeds. Therefore, a great contribution of our First President to the international relations development will be recorded as the history of our famous ancestor Amir Temur and will remain as an invaluable and precious inheritance to the Uzbek people.

The main development principles of the "Uzbek model" have turned into the nationwide slogans: "Uzbekistan is a state with a great future", "Independence - is, the law, first of all", "Don't destroy the old house without constructing an old one", "Reforms are not for reforms themselves but for the person", "The Uzbek people will never depend on anyone", "Let us have a free and prosperous homeland" which constitute the modern theory of the socio-economic development and serve as a basis for the thousand years development of the Uzbek nation.

In addition, our people refer all the results and accomplishments achieved during a short period of time particularly to the name of the First President 


\begin{tabular}{l|lr|ll|ll} 
& ISRA (India) & $=\mathbf{1 . 3 4 4}$ & SIS (USA) & $=\mathbf{0 . 9 1 2}$ & ICV (Poland) & $=\mathbf{6 . 6 3 0}$ \\
Impact Factor: & ISI (Dubai, UAE) $=\mathbf{0 . 8 2 9}$ & PUHL (Russia) $=\mathbf{0 . 2 0 7}$ & PIF (India) & $=\mathbf{1 . 9 4 0}$ \\
& GIF (Australia) & $=\mathbf{0 . 5 6 4}$ & ESJI (KZ) & $=4.102$ & IIBI (India) & $=\mathbf{4 . 2 6 0}$ \\
& JIF & $=\mathbf{1 . 5 0 0}$ & SJIF (Morocco) & $=\mathbf{2 . 0 3 1}$ & & \\
\hline
\end{tabular}

Islam Karimov, and consider them to be unique merits of the great state leader.

The First President Islam Abduganiyevich Karimov will live forever in our memory and hearts as the founder of the independent state, the great statesman and policy-maker, patriot and devoted child for the Uzbek people.

\section{References:}

1. (2014) Constitution of the Republic of Uzbekistan. -T.: "Uzbekistan", 2014.

2. Islam Karimov (2011) "Uzbekistan is on the threshold of independence", "Uzbekistan", T:.2011. 300 p.

3. Kodirov A. (2011) "The principles and basic priorities of the "Uzbek model" of building a democratic society", "economy and innovation technologies" - scientific electronic journal. № 1, September, 2011.

4. Karimov I.A. (1992) "Uzbekistan - its own way of renewal and progress"-T.: "Uzbekistan", 1992.

5. (2017)

Available: http://www.worldbank.org/content/dam/Worldb ank/document/Uzbekistan/

(Accessed: 10.12.2017)

6. (2017) Developed by the author on the basis of the HSBC data.

7. Islam Karimov (2016) 'In life's trials a worthy people of Kashkadarya can achieve any accomplishments"/ I. karimov. -T.: «Uzbekistan», 2016. - 28 p.
8. (2017)

Available:

http://namnews.uz/content/The_Japan_Times_i slom karimov uzbek halining buyuk farzan di.html (Accessed: 10.12.2017).

9. Sh.M. Mirziyoyev (2016) Speech at the joint session of the Legislative Chamber and Senate made on September 9, 2016.

10. Karimov I.A. (1998) There is no future without historical memory. - T.: Uzbekistan, 1998.

11. Karimov I.A. (2004) Our main task is to strengthen our prosperity and consistently follow the path of reforms. - T.: Uzbekistan, 2004.

12. Karimov I.A. (2004) On the way of moral growth connected with peace in our motherland, power of our security, solidarity of our people and their strong will. - T.: Uzbekistan, 2004.

13. (2017) The Decree of the President of the Republic of Uzbekistan № 2744 “On perpetuation of the memory of Islam Abduganiyevich Karimov, the First President of the Republic of Uzbekistan". 